\title{
PENGARUH SERVICE QUALITY DAN SOCIAL INTERACTION TERHADAP PURCHASE INTENTION
}

\author{
Yuni Elisa Suyani* \\ Verina Halim Secapremana \\ Fakultas Bisnis dan Ekonomika, Universitas Surabaya \\ Jl. Mejoyo II No. 13, Kali Rungkut, Kec. Rungkut, Kota Surabaya, Jawa Timur 60293 \\ Email: s134118513@student.ubaya.ac.id*, verina@staff.ubaya.ac.id
}

\begin{abstract}
ABSTRAK
Penelitian dilakukan untuk mengetahui besarnya pengaruh interaksi terhadap minat beli. Sehingga dapat meningkatkan pelayanan dan minat beli nasabah. Interaksi yang diukur dengan service quality dan social interaction, dengan menggunakan customer satistfaction dan customer trust sebagai jembatan untuk meningkatan purchase intention. Responden penelitian adalah nasabah 160 aktif PT Prudential Life Assurance. Penelitian menggunakan pendekatan kualitatif dan menggunakan metode SEM pada AMOS untuk pengolahan data. Didapatkan bahwa Service Quality berpengaruh terhadap purchase intention. Sedangkan Social Interaction tidak sepenuhnya mempengaruhi Purchase Intention secara langsung. Dibutuhkan usaha lebih untuk membangun hubungan dapat dilakukan dengan memberikan waktu yang lebih kepada nasabah untuk berinteraksi dan memberikan respon. Sehingga terdapat kepercayaan dalam hubungan internal yang dimiliki agen dan nasabah.
\end{abstract}

Kata Kunci: pemasaran, pemasaran relational, tenaga pemasaran

\begin{abstract}
The study was conducted to determine the magnitude of the interaction effect on buying interest. So that it can improve customer service and buying interest. Interactions are measured by service quality and social interaction, using customer satisfaction and customer trust as a bridge to increase purchase intention. Research respondents were 160 active customers of PT Prudential Life Assurance. The study used a qualitative approach and used the SEM method on AMOS for data processing. It was found that Service Quality had an effect on purchase intention. While Social Interaction does not fully affect Purchase Intention directly. More effort is needed to build relationships, which can be done by giving customers more time to interact and respond. So that there is trust in the internal relationships between agents and customers.
\end{abstract}

Keywords: marketing, relationship marketing, sales person

\section{DOI: https://doi.org/10.24123/jeb.v25i2/4892}

\section{PENDAHULUAN}

Berdasarkan data yang didapatkan dari AAJI pendapatan asuransi Indonesia pada kuartal ke-3 mengalami peningkatan $11.54 \%$. Meskipun begitu peningkatan yang terjadi belum menunjukkan bahwa peningkatan penetrasi meningkat. Menurut data dari AAJI masih rendah karena hanya 6.5\% masyarakat Indonesia yang telah terproteksi asuransi jiwa (Astutik, 2021). Beberapa penelitian yang menghubungkan rendah penetrasi diakibatkan rendahnya literasi asuransi. Berdasarkan data statistik Otoritas Jasa Keuangan (OJK) (2021) literasi keuangan pada 2019 berada pada angka 38.03\% dan inklusi jasa keangan mencapai angka 76.19\%. Terdapat kesenjangan pada angka literasi dan inklusi tersebut yang menarik untuk dibahas. Kesenjangan tersebut menunjukkan dari 100 orang terdapat 76 orang yang memiliki akses untuk mendapatkan jasa keuangan, tetapi hanya 38 orang saja yang mengerti dan dapat menggunakan produk keuangan.

OJK (2021) menjelaskan produk asuransi jiwa pengetahuan masyarakat adalah 58,74\%. Jika dibedah kembali pengetahuan mengenai asuransi lebih banyak hanya mengetahui manfaat produk yaitu $55.35 \%$, sedangkan cara untuk memperoleh produk hanya $24,27 \%$. Pada sisi penyedia layanan, jumlah agen asuransi jiwa di Indonesia yaitu 610.744 dan $39.78 \%$ adalah agen asuransi PT Prudential Life Assurance. Seharusnya, Prudential sebagai pemimpin pasar mampu untuk meningkatkan penetrasi asuransi. Peningkatan penetrasi sering kali dikaitkan dengan performa agen. Pada aktivitas bisnisnya Prudential menggunakan agen sebagai alat distribusi, karena produkasuransi merupakan produk yang customize dan tidak berupa barang hanya berupa kontrak atau polis saja. Sehingga interaksi antara agen dan nasabah digunakan untuk mengukur minat beli nasabah.

Interaksi antara agen dan nasabah memberikan pengaruh terhadap minat beli. Berdasarkan data AAJI sampai dengan tahun 2020 hasil penjualan asuransi dari agen masih lebih besar dibandingkan dengan bancassurancedan telemarketing. Selain adanya kesenjangan antara literasi dan inklusi penelitian dilakukan 
karena adanya ketertarikan mengenai interaksi antara agen asuransi dan nasabah. Interaksi tersebut memberikan pengaruh terhadap persepsi nasabah mengenai asuransi sehingga memengaruhi minat beli nasabah. Salah satu cara untukmemengaruhi nasabah adalah melalui edukasi mengenai resiko dan penglolaan uang. Dengan cara tersebut agen dapat mendorong emosi nasabah untuk dapat merasakan dan merespon sehingga interaksi lebih dinamis. Untuk dapat meningkatkan respon positif, agen asuransi diharuskan untuk menciptakan kepercayaan internal yang kuat yang memberikan jaminan pelayanan berkelanjutan, dan meningkatkan pengalaman nasabah dalampenggunaan produk (Bachrach dll, 2016). Poin-poin tersebut yang menggeser strategi yang digunakan dalam pemasaran asuransi yang berfokus kepada customer centricapproach.

Sejalan dengan pendapat Schiffman dan Kanuk (2015) yang menyatakan bahwa personal selling dapat mempengaruhi sikap nasabah. Sikap adalah kecenderungan yang dipelajari dalam berperilaku dengan cara yang menyenangkan atau tidak menyenangkan terhadap produk atau layanan. Tanpa adanya personal selling, perusahaan akan kesulitan untuk menentukan kebutuhkan calon nasabah. Keunggulan berikutnya, agen asuransi dapat berkomunikasi secara langsung dengan calon nasabah potensial, sehingga dapat menjadi alat komunikasi pemasaran yang lebih efektif (Kotler dll, 2018). Untuk mendorong minatbeli calon nasabah perlu adanya dukungan emosional dan kecukupan informasi. Dukungan tersebut diwujudkan melalui komunikasi atau interaksi secara langsung dengan calon nasabah, sehingga agen asuransi mendapatkan respon langsung yang menentukan tingkat kualitas layanan dan kepercayaan nasabah.

Service Quality merupakan interaksi yang dibutuhkan untuk menunjukkan jaminan jangka Panjang yang dibutuhkan nasabah. Agen dibutuhkan untuk memberikan kepastian bahwa polis dan perusahaan asuransi dapat menjalankan fungsinya. Pelayanan sendiri diukur melalui kepuasan nasabah yang menunjukkan perbedaan antara harapan dan keadaan yang terjadi sesungguhnya. Ikatan emosional yang dibangun oleh agen memungkinkan untuk memahami dengan seksama harapan dan kebutuhan spesifik konsumen (Lupiyoadi, 2016). Selain itu, pelayanan juga meningkatkan kepercayaan terhadap agen, produk dan perusahaan asuransi. Pemenuhan terhadap harapan nasabah akan memberikan rasa aman ketika melakukan transaksi. Kedua hal ini kepuasan dan kepercayaan nasabah akan meningkatan minat beli. Tjiptono (2016) menjelaskan dimensi dalam pelayanan yang harus dipenuhi untuk meningkatan kepuasan dan kepercayaan nasabah yaitu bukti langsung (tangible), keandalan (reliability), daya tanggap (responsiveness), jaminan (assurance), dan empati (emphaty).

$\mathrm{H}_{1}$ : Service Quality berpengaruh positif terhadap Customer Satisfaction

$\mathrm{H}_{2}$ Service Quality berpengaruh positif terhadap Customer Trust

$\mathrm{H}_{5}$ : Customer Satisfaction berpengaruh positif terhadap Purchase Intention

$\mathrm{H}_{6}$ : Service Quality berpengaruh positif terhadap Purchase Intention

Social interaction yang dijelaskan melalui teori social exchange (teori pertukaran sosial) (Ghahtarani dll, 2020) menyebutkan dalam membangun sebuah hubungan dibutuhkan pertukaran ekonomi dari utilitas fungsional yang sesuai dengan produk/layanan. Dalam konteks personal selling, agen asuransi melakukan interaksi, dan berusaha untuk memaksimalkan nilai dari hubungan; hasilnya yang mengarah pada keterlibatan, kelanjutan, atau penghentian hubungan. Pulga (2019) menjelaskanbahwa interaksi tersebut akan meningkatan exit berier dari hubungan. Dijelaskan lebih lanjut bahwa empati dalam hubungan tersebut menimbulkan kepercayaan. Sehingga ketika dalam masa pendekatan, nasabah akan menilai sikap dan performa kerja agen. Diharapkan ketika kepercayaan telah terbentuk, maka minat beli juga semakin tinggi.

Menurut Godes (2005) social interaction dalam konteks marketing merupakan tindakkan oleh individu yang tidak berfokus pada kegiatan penjualan, tetapi meningkatkan utilitas (kegunaan) produk atau layanan tersebut. Dalam hal ini kegiatan interaksi hanya berfokus pada peningkatan kepercayaan. Chua (2002) dalam tulisannya menjelaskan dimensi interaksi dimulai dari mengenal lingkungan dari nasabah dan cara agenagar dapat masuk dalam lingkungan tersebut. Dimulai dengan mengenal hubungan yang dimiliki antara agen dan nasabah, semakin dekat dengan nasabah tersebut maka akan semakin mudah untuk mencapai kesepakatan, tahap ini disebut sebagai structural dimension. Kedua, frekuensi banyaknya interaksi yang dilakukan untuk meningkatkan kepercayaan tersebut didapat dari jumlah kunjungan yang mengindikasikan kepedulian, tahap ini disebut relational dimension. Ketiga, penyamaan bahasa dan kesepahaman dalam beberapa aspek percakapan sehingga dapat membuat nyaman nasabah, tahap ini disebut cognitive dimension.

$\mathrm{H}_{3}$ : Social Interaction berpengaruh positif terhadap Customer Trust 
$\mathrm{H}_{4}$ : Customer Trust berpengaruh positif terhadap Purchase Intention

$\mathrm{H}_{7}$ : Social Interaction berpengaruh positif terhadap Purchase Intention

\section{METODE PENELITIAN}

Metode penelitian yang digunakan adalah kuantitatif yang menggunakan pengukuran skala likert. Responden yang digunakan adalah 160 nasabah aktif prudential. Pengambilan data menggunakan jenis probability sampling. Pengolahan data, diawali dengan uji deskriptif dan kualitas data pada SPSS. Selanjutnya, menggunakan pengolahan data menggunakan pengukuran persamaan struktural Structural Equation Model (SEM) pada Analisis of Moment Structures (AMOS). Tahapan pengukuran dalam AMOS adalah uji CFA danuji hipotesis.

Simple Linear Regression digunakan ketika terdapat hipotesis tertolak. Rancangan pengujian hipotesis dilakukan dengan membentuk model sederhana. Sedangkan untuk varibel bebas dengan dimensi digunakan multiple linear regression. Teknik regresi linier berganda digunakan untuk mengetahui pengaruh signifikan variabel bebas terhadap variabel terikat (Montgomery dll, 2021).

Gambar 1

Model penelitian

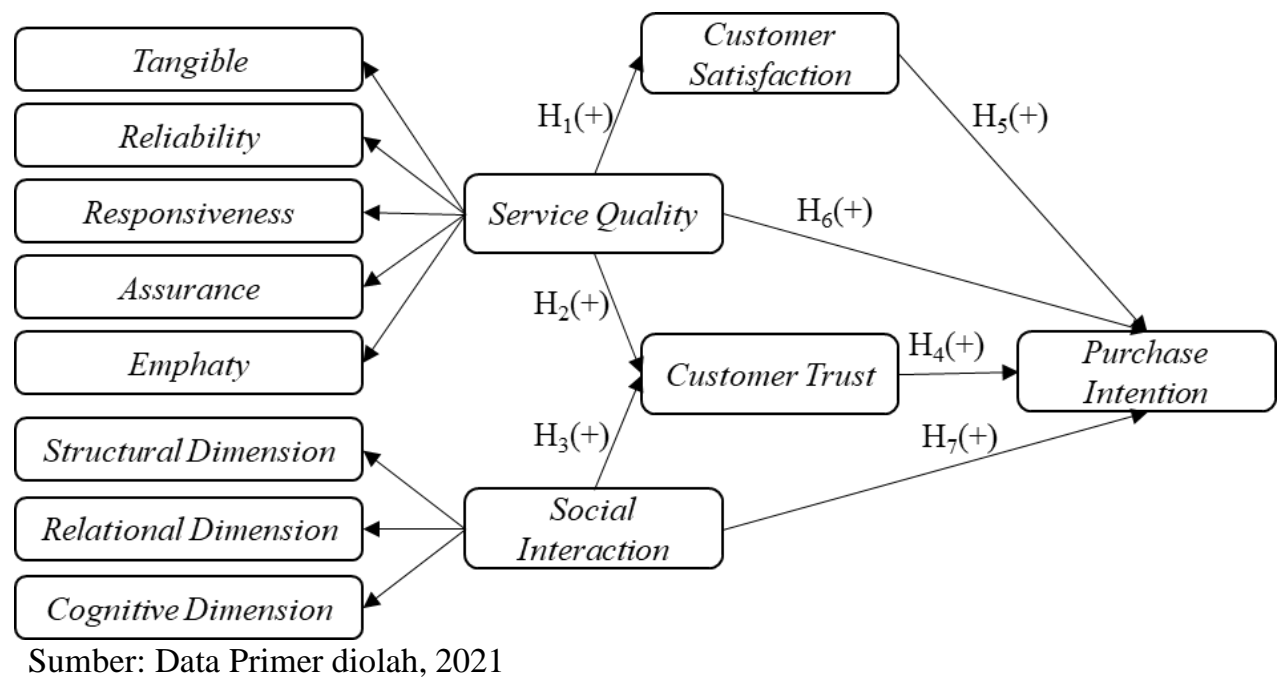

\section{HASIL DAN PEMBAHASAN}

Dari 160 responden yang terkumpul dilakukan klasifikasi untuk memudahkan melihat karakteristik responden dan menunjukkan bahwa 100\% responden memiliki polis asuransi jiwa Prudential yang masih aktif dan pernah menggunakan jasa agen asuransi untuk membantu pendaftaran rawat inap di dalam dan luar negeri, klaim, dan reimburse. didapatkan bahwa profil responden $51.3 \%$ atau sebanyak 82 orang berjenis kelamin laki-laki dan $48.8 \%$ atau sebanyak 78 orang berjenis kelamin perempuan. Profil responden $40.6 \%$ atau 65 orang berumur 26-39 tahun, $23.8 \%$ atau 38 orang berumur $40-55$ tahun, $22.5 \%$ atau 36 orang berumur 21-25, dan $13.1 \%$ atau 23 orang berumur 56-65 tahun. Hasil rata-rata respon dari golongan tersebut tertera di Tabel 1.

Tabel 1

Rata-Rata Tanggapan Responden

\begin{tabular}{lccccccc}
\hline & Total & Perempuan & Laki-Laki & $\mathbf{2 1 - 2 5}$ & $\mathbf{2 6 - 3 9}$ & $\mathbf{4 0 - 5 5}$ & $\mathbf{5 6 - 6 5}$ \\
\hline & $100 \%$ & $48.8 \%$ & $51.3 \%$ & $40.6 \%$ & $23.8 \%$ & $22.5 \%$ & $14.4 \%$ \\
Service Quality & 4.01 & 3.92 & 4.09 & 4.12 & 3.99 & 3.94 & 3.99 \\
Tangible & 3.98 & 3.84 & 4.05 & 4.10 & 3.91 & 3.91 & 3.88 \\
Reliable & 4.03 & 3.93 & 4.13 & 4.19 & 3.99 & 3.97 & 3.99 \\
Responsiveness & 3.91 & 3.85 & 3.98 & 3.99 & 3.93 & 3.81 & 3.94 \\
Assurance & 3.96 & 3.89 & 4.04 & 4.10 & 3.93 & 3.91 & 3.94 \\
\hline
\end{tabular}




\begin{tabular}{cccccccc}
\hline & Total & Perempuan & Laki-Laki & $\mathbf{2 1 - 2 5}$ & $\mathbf{2 6 - 3 9}$ & $\mathbf{4 0 - 5 5}$ & $\mathbf{5 6 - 6 5}$ \\
\hline Emphaty & 4.18 & 4.10 & 4.25 & 4.23 & 4.18 & 4.11 & 4.21 \\
Social Interaction & 4.16 & 4.01 & 4.30 & 4.15 & 4.13 & 4.24 & 4.12 \\
Structural Dimension & 4.19 & 4.04 & 4.33 & 4.26 & 4.13 & 4.32 & 4.01 \\
Relational Dimension & 4.08 & 3.93 & 4.22 & 4.06 & 4.11 & 4.06 & 4.05 \\
Cognitive Dimension & 4.21 & 4.07 & 4.34 & 4.13 & 4.15 & 4.32 & 4.30 \\
\hline
\end{tabular}

Sumber: Data Primer, diolah 2021

Tanggapan nasabah prudential terhadap pelayanan, interaksi, kepercayaan, kepuasan dan minat beli polis asuransi, sebagai berikut:

a. Terhadap pelayanan yang diberikan oleh agen asuransi, nasabah merasa agen asuransi memiliki empati yang tinggi dan dapat diandalkan. Rasa empati terpenuhi dengan berpenampilan yang rapi dan bersih setiap kali bertemu dan berupaya untuk memahami keinginan nasabah. Perhatian dapat berupa banyak hal, penampilan dapat membuat persepsi bahwa agen menghargai nasabah yang telah meluangkan waktu untuk bertemu. Selain itu, agen berusaha untuk memahami keinginan nasabah menunjukkan bahwa agen bersedia untuk membantu nasabah dalam bertansaksi dan penggunaan produk. Produk asuransi merupakan produk yang memiliki banyak riders atau tambahan perlindungan yang perlu dipahami oleh nasabah. Tugas agen dalam hal ini adalah untuk membantu nasabah memutuskan jenis produk yang harus dimiliki nasabah. Dalam penggunaan produk agen asuransi membantu proses pendaftaran perawatan di dalam maupun di luar negeri, klaim dan reimbursement.

$b$. Terhadap interaksi nasabah dapat menerima agen asuransi, karena memiliki kesamaan pemahaman, menggunakan bahasa yang sama, dan dapat berbagi bercerita. Kesamaan bahasa dapat membantu nasabah untuk mendapatkan komunikasi yang baik. Ketika komunikasi telah berjalan dengan lancar, masingmasing pihak bertukar informasi melalui cerita. Masing-masing pihak berbagi cerita mengenai pengalaman dalam penggunaan asuransi. Lalu dilanjutkan dengan bertukar pikiran dan pendapat yang akhirnya akan memiliki kesepahaman mengenai nilai dan kebutuhan nasabah. Nilai tersebut menunjukkan bahwa nasabah memiliki pemahaman yang sama dengan agen asuransi nasabah muncul saat berbagi cerita pengalaman. Dibuktikan dengan diskusi yang dilakukan selama dalam proses pendekatan dan presentasi.

\section{Hasil Uji CFA}

Hasil uji CFA yang digunakan untuk mengetahui adanya kecocokan model dengan variabel yang terwakili. Nilai kecocokan model dijelaskan oleh Sharma et al (2005) nilai indeks GFI dapat diabaikan karena nilai dari RMSEA dan TLI telah menunjukkan indikasi good fit. Hasil tersebut menunjukkan bahwa model yang diuji sudah memenuhi kriteria yang disyaratkan.

Tabel 2

Hasil Uji CFA

\begin{tabular}{cccc}
\hline INDEKS & KRITERIA & Hasil & Keterangan \\
\hline CMIN/DF & CMIN/DF $\leq 2$ & 1,610 & Good fit \\
RMSEA & RMSEA $\leq 0,08$ & 0,062 & Good fit \\
GFI & GFI $0,8-0,9$ & 0,865 & Marginal fit \\
CFI & CFI $\geq 0,9$ & 0,944 & Good fit \\
TLI & TLI $\geq 0,9$ & 0,953 & Good fit \\
\hline
\end{tabular}

Sumber: Data Primer, diolah 2021

\section{Hasil Uji validitas dan reliabititas}

Tabel 3 menunjukkan hasil AVE dan C.R pada setiap variabel yang diukur. Kriteria nilai AVE harus $>0.5$ dan C.R. > 0.6. Hasil olah data pada tabel 3 menunjukkan bahwa variabel service quality, social interaction, customer trust dan purcahse intention memiliki nilai AVE dan C.R lebih dari kriteria yang ditentukan. Sedangkan customer satifaction belum memenuhi, menurut Fornel dan Larcker (1981) jika AVE dibawah 0.5 tetapi diatas 0.4 dan C.R. diatas 0.6, maka variabel dapat dinyatakan valid. Sehinggaseluruh variabel telah memenuhi syarat uji validitas dan reliabilitas model pengukuran. Selanjutnya dapat dilakukan pengujian model struktural dan pengujian hipotesis. 
Tabel 3

Uji validitas dan reliabititas

\begin{tabular}{|c|c|c|c|}
\hline Indikator & Kode & $\boldsymbol{C R}$ & AVE \\
\hline Service quality (Panigrahi dll, 2018) & & 0.923 & 0.705 \\
\hline \multicolumn{4}{|l|}{ Bukti Langsung (Tangible) } \\
\hline Fasilitas kantor pemasaran yang dikatakan agen asuransi terbukti ada & TN1 & & \\
\hline Agen asuransi memiliki penampilan yang rapi dan baik & TN2 & & \\
\hline $\begin{array}{l}\text { Agen asuransi menggunakan alat untuk menjelaskan produk atau layanan } \\
\text { yang didapat }\end{array}$ & $\mathrm{TN} 3$ & & \\
\hline \multicolumn{4}{|l|}{ Keandalan (Reliability) } \\
\hline Agen asuransi menepati janji pada waktu yang tepat & RL1 & & \\
\hline Agen asuransi menyelesaikan masalah dengan tulus & RL2 & & \\
\hline Agen asuransi memberikan pelayanan yang tepat di awal pertemuan & RL3 & & \\
\hline $\begin{array}{l}\text { Agen asuransi memberikan pelayanan diberikan pada waktu yang sesuai, } \\
\text { seperti apa yang telah dijanjikan }\end{array}$ & RL4 & & \\
\hline $\begin{array}{l}\text { Agen asuransi berfokus menyediakan pelayanan bebas kesalahan (tidak } \\
\text { pernah salah) kepada nasabah }\end{array}$ & RL5 & & \\
\hline \multicolumn{4}{|l|}{ Daya tanggap (Responsiveness) } \\
\hline $\begin{array}{l}\text { Agen asuransi menginformasikan kepada nasabah kapan saja jasa mereka } \\
\text { dapat digunakan }\end{array}$ & RS1 & & \\
\hline Agen asuransi akan melayani nasabah dengan sebaik mungkin & $\mathrm{RS} 2$ & & \\
\hline Agen asuransi selalu bersedia membantu kapanpun dibutuhkan & RS3 & & \\
\hline Agen asuransi akan merespon permintaan nasabah & RS4 & & \\
\hline \multicolumn{4}{|l|}{ Jaminan (Assurance) } \\
\hline Agen asuransi mengerti persyaratan / permintaan khusus nasabah & AS1 & & \\
\hline $\begin{array}{l}\text { Agen asuransi meningkatkan rasa percaya diri nasabah untuk menggunakan } \\
\text { produk asuransi }\end{array}$ & AS2 & & \\
\hline Nasabah merasa aman saat melakukan transaksi pada produk asuransi & AS3 & & \\
\hline Agen asuransi selalu berlaku sopan kepada nasabah & AS4 & & \\
\hline \multicolumn{4}{|l|}{ Empati (Emphaty) } \\
\hline Agen asuransi menyediakan perhatian penuh pada nasabah & EM1 & & \\
\hline $\begin{array}{l}\text { Agen asuransi bekerja pada waktu yang tidak menyusahkan (sesuai) untuk } \\
\text { nasabah }\end{array}$ & EM2 & & \\
\hline Agen asuransi terlihat rapi dan baik & EM3 & & \\
\hline $\begin{array}{l}\text { Agen asuransi memiliki berkeinginan untuk memberikan pelayanan yang } \\
\text { terbaik }\end{array}$ & EM4 & & \\
\hline Social Interaction (Chua, 2002) & & 0.853 & 0.628 \\
\hline \multicolumn{4}{|l|}{ Structural dimension } \\
\hline Nasabah mendiskusikan kebutuhan asuransi kepada agen asuransi & SD1 & & \\
\hline $\begin{array}{l}\text { Nasabah menghabiskan waktu yang lama untuk berdiskusi dengan agen } \\
\text { asuransi }\end{array}$ & $\mathrm{SD} 2$ & & \\
\hline Nasabah merasa bahwa agen asuransi dapat dipercaya dan diandalkan & SD3 & & \\
\hline Agen asuransi berempati dan dapat menempatkan posisi pada nasabah & SD4 & & \\
\hline \multicolumn{4}{|l|}{ Relational dimension } \\
\hline Agen asuransi membantu anda setiap kali anda membutuhkan & RD1 & & \\
\hline Nasabah mentolerir kesalahan yang dibuat oleh agen asuransi & RD2 & & \\
\hline
\end{tabular}




\begin{tabular}{|c|c|c|c|}
\hline Indikator & Kode & CR & AVE \\
\hline $\begin{array}{l}\text { Nasabah dapat dengan bebas dan terbuka berpendapat dalam menentukan } \\
\text { produk asuransi }\end{array}$ & RD3 & & \\
\hline Nasabah dan agen asuransi menentukan program bersama-sama & RD4 & & \\
\hline $\begin{array}{l}\text { Nasabah menghargari keberagaman / perbedaan yang dimiliki oleh agen } \\
\text { asuransi }\end{array}$ & RD5 & & \\
\hline $\begin{array}{l}\text { Nasabah dan agen asuransi terbuka terhadap kritik yang diberikan oleh } \\
\text { masing-masing pihak }\end{array}$ & RD6 & & \\
\hline $\begin{array}{l}\text { Nasabah akan mentolerir pada saat agena asuransi gagal dalam melakukan } \\
\text { tugas (contohnya, proses klaim yang lama atau gagal) }\end{array}$ & RD7 & & \\
\hline Nasabah merasakan kebersamaan dengan agen asuransi & RD8 & & \\
\hline \multicolumn{4}{|l|}{ Cogntive dimension } \\
\hline Agen asuransi memiliki kemampuan berkomunikasi yang baik & CD1 & & \\
\hline $\begin{array}{l}\text { Nasabah menggunakan bahasa non-formal, klise, atau istilah-istilah santai } \\
\text { dalam berdiskusi dengan agen asuransi }\end{array}$ & $\mathrm{CD} 2$ & & \\
\hline Nasabah dapat berbagi cerita dengan agen asuransi & CD3 & & \\
\hline Customer trust (Panigrahi dll, 2018) & & 0.853 & 0.628 \\
\hline $\begin{array}{l}\text { Nasabah memperhatikan masalah keamanan pada saat membeli produk } \\
\text { asuransi }\end{array}$ & CT1 & & \\
\hline Nasabah percaya pada perkataan dan janji yang diberikan & СT2 & & \\
\hline $\begin{array}{l}\text { Agen asuransi harus dapat memenuhi kewajibannya untuk meningkatkan } \\
\text { kepercayaan nasabah }\end{array}$ & СТ3 & & \\
\hline Nasabah dapat mengandalkan produk asuransi jiwa & CT4 & & \\
\hline Customer satisfaction (Panigrahi dll, 2018) & & 0.785 & 0.479 \\
\hline Nasabah akan mengulang pembelian polis asuransi & CS1 & & \\
\hline Nasabah bersedia untuk menceritakan pengalaman kepada orang lain & $\mathrm{CS} 2$ & & \\
\hline $\begin{array}{l}\text { Nasabah berpikir telah mengambil keputusan yang benar dengan membeli } \\
\text { produk asuransi }\end{array}$ & CS3 & & \\
\hline Secara keseluruhan nasabah merasa puas dengan produk asuransi & CS4 & & \\
\hline Purchase intention (Panigrahi dll, 2018) & & 0.813 & 0.522 \\
\hline Saya bermaksud untuk membeli produk asuransi jiwa & PI1 & & \\
\hline Saya sangat bersedia untuk membeli produk asuransi & PI2 & & \\
\hline Saya mungkin akan membeli produk asuransi & $\mathrm{PI} 3$ & & \\
\hline Saya sangat berniat untuk membeli produk asuransi & PI4 & & \\
\hline
\end{tabular}

Sumber: Data Primer, diolah 2021

\section{Hasil Hipotesis}

Pengujian hipotesis menunjukkan H1 sampai dengan H6 didukung. Pengaruh Service Quality terhadap Customer Satisfaction, Service Quality terhadap Customer Trust, Social Interaction terhadap Customer Trust, Customer Trust terhadap Purchase Intention, Customer Satisfaction terhadap Purchase Intention, Service Quality terhadap Purchase Intention. Sedangkan, H7 pengaruh Social Interaction terhadap Purchase Intention tidak didukung, lihat di Tabel 4.

Tabel 4

Hipotesis

\begin{tabular}{cccccc}
\hline Hipotesis & Hubungan Variabel & Estimate & C.R. & P & Keterangan \\
\hline $\mathrm{H} 1(+)$ & $\mathrm{SQ} \rightarrow \mathrm{CS}$ & 0.726 & 6.814 & $* * *$ & didukung \\
$\mathrm{H} 2(+)$ & $\mathrm{SQ} \rightarrow \mathrm{CT}$ & 0.538 & 4.749 & $* * *$ & didukung \\
$\mathrm{H} 3(+)$ & $\mathrm{SI} \rightarrow \mathrm{CT}$ & 0.407 & 4.032 & $* * *$ & didukung \\
$\mathrm{H} 4(+)$ & $\mathrm{CT} \rightarrow \mathrm{PI}$ & 0.356 & 2.618 & 0.009 & didukung \\
$\mathrm{H} 5(+)$ & $\mathrm{CS} \rightarrow \mathrm{PI}$ & 0.314 & 2.389 & 0.017 & didukung \\
\hline
\end{tabular}




\begin{tabular}{lcrccc}
\hline Hipotesis & Hubungan Variabel & Estimate & C.R. & \multicolumn{1}{c}{ P } & Keterangan \\
\hline H6(+) & SQ $\rightarrow$ PI & 0.527 & 4.137 & $* * *$ & didukung \\
H7 $(+)$ & SI $\rightarrow$ PI & 0.031 & 0.333 & 0.739 & Tidak didukung \\
\hline
\end{tabular}

Sumber: Data Primer, diolah 2021

Hasil penelitian menunjukkan bahwa pelayanan mampu meningkatkan kepuasan dan kepercayaan nasabah terhadap polis asuransi yang dibeli. Untuk itu peningkatan juga perlu dilakukan karena melalui pelayanan tersebut dapat meningkatan empati nasabah. Hasil penelitan ini sesuai dengan penelitian yang dilakukan oleh Tjiptono (2016) yang mendapatkan bahwa secara umum pelayanan dapat meningkatkan kepuasan dan minat beli nasabah. Berdasarkan penelitian yang sama didapatkan pula bahwa pada variabel pelayanan dimensi empati dan keandalan merupakan dimensi yang memberikan pengaruh terbesar dalam meningkatkan minat beli. Banyak nasabah yang beranggapan agen asuransi sebagai jembatan mereka untuk melihat kinerja produk dan perusahaan asuransi. Produk asuransi sebagai produk intangible akanbergantung pada agen asuransi sebagai alat pendistribusiannya. Oleh karena itu, agen asuransi harus berusaha untuk meyakinkan nasabah. Salah satunya dengan menunjukkan dan memberi informasi yang jelas mengenai fasilitas kantor yang dapat dikunjungi, fasilitas perlindungan yang didapatkan, hak dan kewajiban yang didapat secara transparan. Selain itu lebih penting untuk mendapatkan perhatian lebih dengan berpakaian rapi pada saat bertemu dengan nasabah.

Rasa empati nasabah juga didapatkan melalui interaksi yang dilakukan. Pertama melalui penampilan. Penampilan agen pada saat bertemu nasabah menambah poin kepercayaan dan kepuasan. Melalui penampilan nasabah merasa dihargai. Nasabah selalu menginginkan interaksi yang nyaman dan sesuai dengan harapan nasabah. Kedua, agen menyediakan waktu sesuai dengan waktu yang dimiliki oleh nasabah. Ketika nasabah menyediakan waktu untuk berinteraksi dengan agen hal tersebut merupakan kesempatan untuk agen dapat membangun hubungan. Nasabah cenderung merasa nyaman ketika agen tepat waktu ketika memiliki janji temu, karena itu waktu merupakan hal yang penting. Ketiga dengan menunjukkan keandalan agen. Dari pelayanan yang diharapkan nasabah, keandalan agen dalam membantu nasabah menjadi hal yang penting.

Pelayanan agen dalam penjualan polis tidak berhenti ketika nasabah telah membeli polis, tetapi sampai saat nasabah menggunakan polis tersebut. Terdapat di Prudential sendiri terdapat banyak kegiatan yang yang melibatkan nasabah sendiri contohnya konversi produk baru tanpa masa tunggu, promo medical check up, dan cash back. Kegiatan- kegitan tersebut dapat dimanfaatkan agen untuk membangun hubungan dengan nasabah. Sehingga nasabah merasa agen asuransi dapat diandalkan. Seperti pendapat Godes (2005) bahwa semua aktivitasinteraksi harus menambahkan nilai pada utilitas produk, dalam hal ini asuransi. Melalui pelayanan tersebut diharapkan bahwa nasabah akan mereferensikan agen atau produk, sehingga dapat meningkatan minat beli dan penetrasi asuransi di Indonesia.

Interaksi sendiri dapat meningkatkan kepercayaan dan kepercayaan dapat menjembatani minat beli. Dengan adanya interaksi yang dilakukan berulang dapat menghasilkan, membangun, dan memelihara kepercayaan (Palmatier, Dant, Grewal, \& Evans, 2006; dalam Pulga, 2019). Pada penelitian didapatkan bahwa nasabah membangun kepercayaan baik terhadap agen asuransi dan perusahaan penyedia asuransi bahwa keduanya akan bertindak serta memenuhi kewajiban sesuai yang disepakati serta dimengerti oleh nasabah. Kepercayaan juga akan terbentuk terhadap produk bahwa produk akan berfungsi seperti yang diharapkan. Berdasarkan hasil yang didapat, pada social interaction terdapat dimensi yang paling memengaruhi yaitu stuctural dimension yaitu kepercayaan nasabah terbentuk berdasarkan cara pendekatan agen asuransi. Hasil penelitian ini sesuai dengan teori personal selling yang disampaikan oleh Jobber (2009, p. 5), yaitu agenasuransi dapat menjadi alat pemasaran yang kefektif karena, kemampuan komunikasi interaktif, menyesuaikan presentasi dengan kebutuhan, membuat argumen kompleks untuk mengatasi penolakan,dan dapat membangun hubungan dengan nasabah.

Pada social interaction dimensi yang paling memengaruhi adalah stuctural dimension. Dimana pendekatan awal dilakukan. Pada tahap awal ini agen harus mampu menciptakan kondisi yang nyaman sehingga nasabah bersedia untuk bertemu. Pada umumnya nasabah akan lebih terbuka ketika agen berkenalan melalui refrensi. Artinya, agen harus memetakan lingkaran lingkungannya. Semakin dekat lingkungan tersebut maka nasabah akan semakin terbuka. Pemetaan lingkaran yang dapat digunakan oleh agen asuransi adalah lingkungan pertama yaitu keluarga, lingkaran kedua teman dan kerabat, lingkaran ketiga yaitu hasil refrensi. Setelah agen asuransi mampu memindahkan posisi nasabah pada

DOI: https://doi.org/10.24123/jeb.v25i2/4892 
lingkaran kedua, kepercayaan mulai terbentuk. Sehingga untuk meningkatan kepercayaan nasabah, agen harus dapat membuka ruang diskusi untuk menentukan kebutuhan dan keinginan nasabah. Dengan agen membuka ruang diskusi dengan nasabah dan menentukan pembelian produk bersama menimbulkan persepsi nasabah bebas berpendapat mengenaiproduk yang akan dibeli. Proses diskusi ini akan membantu nasabah untuk menciptakan persepsi positif mengenai agen, produk dan perusahaan asuransi.

Untuk hasil uji hubungan antara social interaction dengan purchase intention tidak didukung. Hasil uji pada hipotesis ke 7 menunjukkan bahwa social interaction dan purchase intention tidak didukung. Sehingga dilakukan uji simple linear regression untuk mendapatkan gambaran jelas pada hububungan dimensi social interaction dengan purchace intention. Uji f digunakan untuk mengetahui pengaruh simultan variabel social interaction terhadap purchase intention. Berdasarkan hasil uji $\mathrm{f}$ didapatkan nilai signifikansi $<0.5$ dan nilai $\mathrm{f}$ hitung $>2.66$. Sehingga diketahui bahwa secara simultan social interaction memengaruhi purchase intention.

Uji r digunakan untuk mengetahui besarnya pengaruh variabel social interaction terhadap purchase intention. Berdasarkan hasil uji $\mathrm{r}$ didapatkan nilai $\mathrm{r}$ sebesar 0.612. Sehingga diketahui bahwa pengaruh social interaction terhadap purchase intention sebesar $61.2 \%$. Dari hasil tersebut diketakui bahwa secara keseluruhan berpengaruh social interaction terhadap purchase intention. Sedangkan $38.8 \%$ variabel terikat dipengaruhi oleh variabel lain diluar model. Dalam beberapa literatur kepercayaan menjadi faktor utama untuk menjembatani peningkatan minat beli.

Hasil uji T menunjukkan variabel structural dimension dan cognitive dimension berada $<0.5$ dan nilai t hitung $>1.975$. Sedangkan sub-variabel relational dimension memiliki nilai signifikansi $>0.5$ dan t hitung $<1.975$. Sehingga diketahui bahwa sub-variabel relational dimension tidak berpengaruh terhadap purchase intention. Pada tahap kedua membangun hubungan kebanyakan dari agen sering kali melewati tahapan membangun dan berfokus pada komunikasi saja. Hal ini yang menyebabkan persepsi negatif dari nasabah yang berganggapan bahwa agen asuransi sebagai pihak yang merugikan.

Pada umumnya agen asuransi akan memiliki daftar nama yang akan dihubungi satu persatu-satu lalu menawarkan produk tanpa menggali lebih dalam kebutuhan nasabah. Untuk merubah hal tersebut beberapa metode pelatihan mengenai komunikasi dengan nasaba harus diperbaiki kembali. Agen asuransi seharusnya membangun hubungan terus-menerus dengan nasabah, sehingga akan terjadi pertukaran informasi antara kebutuhan nasabah dan produk yang disediakan. Lebih baik ketika komunikasi dilakukan terus-menerus tanpa ada indikasi menekan nasabah untuk membeli sebuah produk. Hasil penelitian lebih lagi menemukan bahwa kelompok responden wanita memiliki rata-rata lebih rendah dibandingkan dengan pria pada dimensi relational dimension. Hal ini akan memengaruhi minat beli asuransi, karena di negara Indonesia pihak wanita akan lebih banyak berkontribusi terhadap keputusan sebuah pembelian.

Secara umum terlihat dari tanggapan nasabah mengenai pelayanan dan interaksi yang dilakukan oleh agen asuransi bahwa kelompok perempuan memiliki rata-rata yang lebih rendah dibandingan dengan laki-laki. Hal ini dikarenakan perempuan lebih berhati-hati dan memiliki banyak pertimbangan ketika memutuskan melakukan pembelian. Begitu pula ketika berkenalan ataupun menjalin hubungan laki-laki akan cenderung menggunakan logika dan mempejalari manfaat dan resiko yang akan muncul, sedangkan perempuan akan cenderung tertutup. Disisi lain jika dilihat dari kepemiliki rekening wanita memiliki lebih banyak yaitu 54\% dibandingkan dengan laki-laki pada angka $46 \%$. Artinya wanita lebih banyak mengontrol keuangan dalam keluarga, karena itu agen harus lebih banyak menginvestasikan waktu untuk mengedukasi sampai kepercayaan terhadap agen dan produk semakin besar.

\section{KESIMPULAN DAN SARAN}

Berdasarkan hasil penelitian dan pembahasan terkait interaksi dan minat beli maka dapat disimpulkan bahwa interaksi terbukti berpengaruh positif terhadap minat beli asuransi. Hal ini fitunjukkan dengan adanya kepuasan dan kepercayaan yang memengaruhi minat beli nasabah. Melalui peningkatan kualitas layanan dan interaksi nasabah memiliki minat beli yang tinggi terhadap asuransi. Sedangkan pengaruh social interaction terhadap purchase intention didapatkan hanya secara parsial. Pada social interaction dimensi structural dimension memiliki pengaruh paling kuat sehingga akan lebih baik kertika pertemuan dilakukan dengan lebih santai dan dengan membawa seorang teman yang mengenal keduanya sebagai pencair suasana. 
Pada dimensi relational dimension tidak berhubungan dengan purchase intention karena kurangnya usaha agen untuk lebih mengenal dan berkomunikasi dengan nasabah. Oleh sebab itu agen harus melengkapi diri dengan meningkatan kecerdasan emosional, sehingga mampu mengatasi respon negatif nasabah. Salah satu caranya dengan melakukan kunjungan untuk menjelaskan polis asuransi yang telah dibeli. Respon dari kunjungan tersebut akan didapatkan apakah nasabah masih merasa puas atas pembelian polis. Agen akan selalu kembali merespon terhadap keadaan emosi dan pemikiran nasabah sehingga dapat memelihara hubungan.

Untuk penelitian selanjutnya, pada hasil penelitian didapatkan bahwa pada kelompok responden perempuan belum merasakan adanya hubungan dengan agen asuransi. Sehingga diharapkan pada penelitian selanjutnya meneliti Social Interaction yang dirasakan oleh kelompok responden perempuan. Karena, di Indonesia perempuan akan lebih bertindak sebagai pengelola keuangan keluarga. Akan sangat menarik, ketika mempelajari faktor-faktor yang dapat membangun hubungan dan kepercayaan terhadap nasabah perempuan.

\section{DAFTAR PUSTAKA}

Astutik, Y. (2021, September 09). CNBC Indonesia. Retrieved from CNBC Indonesia News: https://www.cnbcindonesia.com/news/20210909123510-4-274925/termasuk-penetrasi-ini-sederettantangan-asuransi-jiwa-di ri\#: :text=\%22Dari\%20270\%20juta\%20jiwa\%20penduduk,9\%2F9\%2F2021).

Bachrach, D. G., Mullins, R. R., \& Rapp, A. A. (2016). Intangible Sales Team Resources: Investing in Team Social Capital and Transactive Memory for Market-Driven behaviors, Norms and Performance. Elsevier, 12. doi:http://dx.doi.org/10.1016/j.indmarman.2016.08.001

Chua, A. Y. (2002). The Influence of Social Interaction on Knowledge Creation. Journal of Intellectual Capital, 3(4), 375 - 392.

Fornell, C., \& Larcker, D. F. (1981). Evaluating Structural Equation Models with Unobservable Variables and Measurement Error. Journal of Marketing Research, 18(11), 39-50.

Ghahtarani, A., Sheikhmohammady, M., \& Rostami, M. (2020). The Impact of Social Capital dan Social Interaction on Customer's Purchase Intention, Considering Knowledge Sharing in Social Commerce Context. Journal of Inovation and Knowledge, 5(3), 191-199. doi:https://doi.org/10.1016/j.jik.2019.08.004

Godes, D., Mayzlin, D., Chen, Y., Das, S. R., Dellarocas, C., Pfeiffer, B., \& Libai, B. (2005). Interactions, The Firm's Management of Social. Research Gate, 16(3), 415-428. doi:DOI:10.1007/s11002-005-5902-4

Jobber, D., \& Lancaster, G. (2009). Selling and Sales Management (8 ed.). Harlow, England: Pearson Education Limited. Retrieved Oktober 6, 2020

Kotler, P., Keller, K. L., Ang, S. H., Tan, C. T., \& Leong, S. M. (2018). Marketing Management An Asian Perspective 7TH Edition. Country Harlow: Publisher Pearson Education Limited.

Lupiyoadi, R. (2016). Manajemen Pemasaran Jasa Teori dan Praktik. Jakarta: Salemba Empat.

Montgomery, D. C., Peck, E. A., \& Geoffrey, V. G. (2021). Introduction To Lieear Regression Analysis (6 ed.). Hoboken: Wiley.

Otoritas Jasa Keuangan. (2021, Desember 19). Ojk- Berita dan Kegiatan. Retrieved from OJK: https://www.ojk.go.id/id/berita-dan-kegiatan/publikasi/Pages/Strategi-Nasional-Literasi-KeuanganIndonesia-2021-2025.aspx

Panigrahi, S. K., Azizan, N. A., \& Khan, M. W. (2018). Investigating the Empirical Relationship Between Service Quality, Trust, Satisfaction, and Intention of Customers Purchasing Life Insurance Products. Indian Journal of Marketing, 48(1), 28-46. doi:DOI: 10.17010/ijom/2018/v48/11/120734

Pulga, A. A., Basso, K., Ramos, V. K., Pacheco, N. A., Ladeira, W. J., \& Dalla, C. V. (2019). The Link Between Social Interactions and Trust Recovery in Customer-Business Relationships. Wiley, 18, 496504. doi:https://doi.org/10.1002/cb.1788

Schiffman, L. G., \& Wisenblit, J. (2015). Consumer Behavior (11 ed.). New Jersey : Pearson Education, Inc. Sharmaa, S., Soumen, M., Kumarc, A., \& Dillond, W. R. (2005). A Simulation Study to Investigate The Use of Cutoff Values for Assessing Model Fit in Covariance Structure Models. Journal of Business Reseach, 58, 935-943. doi:10.1016/j.jbusres.2003.10.007

Tjiptono, F., \& Chandra, G. (2016). Service, Quality \& Satisfaction (3 ed.). Yogyakarta: Andi. 